\title{
Nutritional evaluation of corn grown using different organic fertilizers for slow-growing broilers
}

\section{Avaliação nutricional do milho cultivado com diferentes adubos orgânicos para frangos de crescimento lento ${ }^{1}$}

\author{
Carla Fonseca Alves Campos ${ }^{2 *}$; Jefferson Costa de Siqueira3; Kênia Ferreira \\ Rodrigues ${ }^{4}$; Roberta Gomes Marçal Vieira Vaz'; Susana Queiroz Santos Mello"; \\ Gerson Fausto da Silva ${ }^{4}$; Danilo Vargas Gonçalves Vieira ${ }^{4}$; Iberê Pereira Parente ${ }^{5}$; \\ Valquíria Sousa Silva ${ }^{6}$, Caroliny Costa Araújo ${ }^{6}$
}

\begin{abstract}
The aim of this study was to evaluate the chemical composition, energy values and nutrient metabolizability coefficients of corn grown using different organic fertilizers and its use for feeding slow-growing broilers. Two experiments were conducted. In the first experiment, two hundred 21-dayold broilers were distributed in a completely randomized design, with five treatments and four replicates of 10 birds per experimental unit. The treatments were a control diet and four test diets (corn fertilized with crotalaria, corn fertilized with millet, corn fertilized with humus, and corn without fertilization), including corn at $30 \%$ in the control diet. The apparent metabolizable energy, apparent metabolizable energy corrected for nitrogen balance, and apparent metabolizability coefficients of dry matter, crude protein and gross energy were determined. In the performance trial, two hundred and fifty 1-day-old chicks were distributed in a completely randomized design into five treatments (T1 - control diet with commercial corn, T2 - corn without fertilization, T3 - corn fertilized with humus, T4 - corn fertilized with millet and T5 - corn fertilized with crotalaria) and five replicates of 10 birds per experimental unit. Weight gain, feed intake, feed conversion and final weight at 20 days were evaluated. The AME and $\mathrm{AME}_{\mathrm{n}}$ values of corn fertilized with crotalaria, millet, humus and corn without fertilization were 3246 and $3239 \mathrm{kcal} \mathrm{kg}^{-1}$; 2965 and $2954 \mathrm{kcal} \mathrm{kg}^{-1}$; 2909 and $2877 \mathrm{kcal} \mathrm{kg}^{-1}$; and 3265 and $3201 \mathrm{kcal} \mathrm{kg}^{-1}$, respectively. The apparent metabolizable coefficients of DM, CP and GE were: $89.75 \%, 66.88 \%$ and $88.5 \%$ for corn fertilized with crotalaria; $84.38 \%, 58.73 \%$ and $81.4 \%$ for corn fertilized with millet; $80.38 \%, 53.45 \%$ and $78.95 \%$ for corn fertilized with humus; and $89.48 \%, 68.95 \%$ and $87.85 \%$ for corn without fertilization, respectively. Feeding broilers with corn cultivated with different fertilizers affected $(\mathrm{P}<0.05)$ weight gain, feed intake, feed conversion and final weight. The treatments using corn fertilized with crotalaria, millet, humus and commercial corn did not differ, with better results in
\end{abstract}

Parte da dissertação de Mestrado do primeiro autor.

2 Discente, Curso de Doutorado do Programa de Pós-Graduação em Ciência Animal Tropical, Universidade Federal do Tocantins, UFT, Araguaína, TO, Brasil. E-mail: carlafazoo@hotmail.com

3 Prof. Dr., Universidade Federal do Maranhão, UFMA, Centro de Ciências Agrárias e Ambientais, Chapadinha, MA, Brasil. E-mail: jcsiqueira@ufma.br

4 Profs. Drs., Departamento de Zootecnia, Escola de Medicina Veterinária e Zootecnia, UFT, Araguaína, TO, Brasil. E-mail: rodrigueskf@mail.uft.edu.br; betagmvvaz@yahoo.com.br; sqsmello@gmail.com; gerson@uft.edu.br; danilovargaszoo@mail. uft.edu.br

5 Prof., Dr., Instituto Federal de Educação Ciência e Tecnologia do Maranhão, IFMA, Presidente Dutra, MA, Brasil. E-mail: iberepereira@hotmail.com

6 Discentes, Curso de Mestrado do Programa de Pós-Graduação em Ciência Animal Tropical, UFT, Araguaína, TO, Brasil. E-mail: walquiria.sousa-zootecnia@hotmail.com; caroliny.cca@gmail.com

* Author for correspondence 
relation to corn crop cultivated without fertilization. The use of crotalaria and millet as a green manure, and humus derived from dairy manure are alternatives that can be used on corn crop as they resulted in grains with adequate nutritional composition, energy values and metabolizable coefficients for slowgrowing broilers from 1 to 20 days of age.

Key words: Green manure. Metabolizable energy. Productive performance.

\section{Resumo}

Objetivou-se no presente trabalho avaliar o milho cultivado com diferentes adubos orgânicos sobre a composição química, valores energéticos, coeficientes de metabolizabilidade dos nutrientes e sua utilização na alimentação de frangos de crescimento lento. Foram realizados dois experimentos, no primeiro experimento foram utilizadas duzentas aves de 21 dias de idade, distribuídas em delineamento inteiramente casualizado, com cinco tratamentos, 4 repetições de 10 aves por unidade experimental. Os tratamentos consistiram de dieta referência e testes (milho adubado com crotalária, milho adubado com milheto, milho adubado com húmus e milho sem adubação), nas quais os milhos substituíram $30 \%$ da dieta referência. Foram determinados avaliados a energia metabolizável aparente, energia metabolizável aparente corrigida para o balanço de nitrogênio, os coeficientes de metabolizabilidade aparente da matéria seca, proteína bruta e energia bruta. No ensaio de desempenho, foram utilizados duzentos e cinquenta pintos de 1 dia, distribuídos em delineamento experimental inteiramente casualizado, com cinco tratamentos ( $\mathrm{T} 1$ - ração referência com milho comercial, $\mathrm{T} 2$ - ração com milho sem adubação, T3 - ração com milho adubado com húmus, T4 - ração com milho adubado com milheto e T5 - ração com milho adubado com crotalária) e cinco repetições de 10 aves por unidade experimental. Foram avaliados o ganho de peso, consumo de ração, conversão alimentar e o peso final aos 20 dias de idade. Os valores determinados de EMA e EMAn dos milhos adubados com crotalária, milheto, húmus e sem adubação foram: 3246 e $3239 \mathrm{Kcal} \mathrm{kg}^{-1}$; 2965 e $2954 \mathrm{Kcal} \mathrm{kg}^{-1}$; 2909 e $2877 \mathrm{Kcal} \mathrm{kg}^{-1} ; 3265$ e $3201 \mathrm{Kcal} \mathrm{kg}^{-1}$, respectivamente, e os coeficientes de metabolizabilidade aparente da MS, PB e EB foram: $89,75 \%$, $66,88 \%$ e $88,5 \%$ para o milho adubado com crotalária; $84,38 \%, 58,73 \%$ e $81,4 \%$ para o adubado com milheto; $80,38 \%, 53,45 \%$ e $78,95 \%$ para o adubado com húmus e $89,48 \%, 68,95 \%$ e $87,85 \%$ para o sem adubação, respectivamente. Observou-se que os milhos cultivados com diferentes adubações afetaram $(\mathrm{P}<0,05)$ o ganho de peso, consumo de ração, conversão alimentar e peso final. $\mathrm{O}$ tratamento do milho adubado com crotalária, milheto, húmus e o milho comercial não diferiram, com melhores resultados em relação ao milho cultivado sem adubação. A adubação verde com crotalária e milheto, seguido do uso de húmus são alternativas que podem ser utilizadas no cultivo do milho, pois propiciaram grãos com composição nutricional, valores energéticos e coeficientes de metabolizabilidade adequados ao desempenho de frangos de crescimento lento de 1 a 20 dias.

Palavras-chave: Adubação verde. Energia metabolizável. Desempenho produtivo.

\section{Introduction}

The improvement of sustainable agricultural practices is a challenge for food production in harmony with the environment. It arose initially as a response to the industrialization process, marked by technification. In the $1980 \mathrm{~s}$, as a result of social pressure to reduce the use of fertilizers and pesticides, the population's eating habits changed, and the search for a better quality of life aroused the interest of consumers, farmers and environmentalists.
Agroecology is a production system that differs from conventional agriculture mainly because it conserves biodiversity, cycles and biological activities of the soil, seeks to promote human health and environmental balance, and is ecologically correct, economically viable and socially just (BARROS; SILVA, 2010).

According to the Comunidade Econômica Européia - CEE (1991), the fertility and biological activity of soils can be adequately conserved 
or improved through the use of green manure, incorporation of animal manure into soils and composting. The action of microorganisms on biodegradable compounds existing or incorporated into the soil allows the supply of chemical elements indispensable to the development of cultivated plants.

Organic fertilizers lead to an adequate balance of mineral nutrition in the plants, in addition to providing better soil conditioning. However, due to their different $\mathrm{C} / \mathrm{N}$ ratios, they influence the mineralization rate of residues and, consequently, the release of nutrients to crops grown in succession (NICOLARDOT et al., 2001).

Knowledge of fertilization is an essential aspect to improve the quality of cereal grains. If it is not appropriate, it can influence the chemical composition of feedstuffs (FRANCESCHI et al., 2009; SILVA et al., 2015). Corn (Zea mays) stands out as one of the main cereals grown in Brazil, mainly in the Midwest, Southeast and South regions. Corn grows under different production systems and has widespread use in poultry feeding due to its productive potential, chemical composition and nutritional value (BRASIL, 2017).

Raising backyard poultry is one of the segments of alternative poultry that has shown promise in Brazil as it adds value to the product through a breeding system that respects animal welfare standards, allowing the bird to express its natural behaviour. This production system serves both small and medium farms as well as large-scale production (MADEIRA et al., 2010; MORAIS et al., 2015).

There is a lack of published information on the use of corn grown with different fertilizers for feeding backyard poultry, as regards chemical composition and energy values, as well as animal performance. Considering this, the aim was to evaluate the effect of different organic fertilizers on the chemical composition, energy values and nutrient metabolizability coefficients of corn grains and their use for feeding slow-growing broilers.

\section{Material and Methods}

Two trials were conducted at the Poultry Research Centre of the School of Veterinary Medicine and Animal Science, Federal University of Tocantins, Araguaína - TO. The first trial was carried out from July $27^{\text {th }}$ to August $3^{\text {rd }} 2014$, and the second from September $15^{\text {th }}$ to November $4^{\text {th }} 2014$. The study was conducted in accordance with the rules of the Ethics Committee on Animal Use, Federal University of Tocantins (CEUA-UFT) under protocol number 23101.003578 2016-51.

The average annual air temperature and precipitation range from $28{ }^{\circ} \mathrm{C}$ and $1800 \mathrm{~mm}$, respectively. The climate is classified as Aw (hot and humid) according to Köppen classification. The corn experimental area has a typical Eutrophic Brown soil and it was in the third crop year.

\section{Soil preparation for corn cultivation}

Establishment of the system started with soil correction with dolomitic limestone at $400 \mathrm{~kg} \mathrm{ha}^{-1}$ and division into four plots of $840 \mathrm{~m}^{2}$ each. Soil preparation was done with subsoil tillage to a depth of $30 \mathrm{~cm}$.

Three plots received one type of fertilization (millet, crotalaria and humus), and one plot did not receive fertilization (control). Millet and crotalaria sowing was carried out in rows spaced $1.0 \mathrm{~m}$ apart. At the early stages of inflorescence (80 days after sowing), the two cultures were cut and later incorporated into the soil using a disk plough. Humus (dairy manure vermicompost) was distributed $(250 \mathrm{~kg})$ by hand.

After the resting period of 10 days (chopped material), application of natural rock phosphate at $50 \mathrm{~kg} \mathrm{ha}^{-1}$ of $\mathrm{P}_{2} \mathrm{O}_{5}$ was carried out. Subsequently, the Bandeirantes corn cultivar was sown in shallow pits spaced $20 \mathrm{~cm}$ apart, with $80 \mathrm{~cm}$ between rows.

Corn was harvested at physiological maturity, when the grains were dry. After harvesting the 
panicles, the grains were removed, cleaned and stored in bags identified according to the treatment, to prepare the experimental diets. Corn used in the control diet was cultivated following conventional methods.

Trial I: Chemical composition (DM, CP, MM, GE and $C F$ ), energy values ( $A M E$ and $A M E_{n}$ ) and apparent metabolizability coefficients (DM, CP and GE) of corn grains from crops cultivated using different organic fertilizers

A total of 200 slow-growing (Red Naked Neck) broilers of both sexes, 21 days old, were used to determine the apparent metabolizable energy (AME), apparent metabolizable energy corrected for nitrogen balance $\left(\mathrm{AME}_{\mathrm{n}}\right)$ and apparent metabolizable coefficients of dry matter (AMCDM), crude protein (AMCCP) and gross energy (AMCGE) of corn grown using different fertilizers, by the traditional method of total excreta collection (ALBINO et al., 1992; SIBBALD, 1976; SIBBALD; SLINGER, 1963).

Broilers were housed in experimental cages $(1.00 \times 1.00 \times 0.40 \mathrm{~m})$ equipped with trough-type feeders and drinkers, a heating system for chicks until the $14^{\text {th }}$ day of life and metal trays immediately below the cages to remove excreta.

On the $21^{\text {st }}$ day, birds with a mean weight of 370 $\pm 11.74 \mathrm{~g}$ were randomly distributed in experimental cages in a completely randomized design with five treatments, four replicates and 10 birds per experimental unit, with the following treatments:

T1: Control diet based on corn and soybean meal formulated to meet the nutritional requirements of semi-heavy chickens in the growing phase, corrected for the average temperature in Araguaína, according to Rostagno et al. (2011) (Table 1).

Table 1. Composition of control diet (organic matter basis).

\begin{tabular}{lc}
\hline Ingredients & $(\%)$ \\
\hline Corn & 61.813 \\
Soybean meal (45\%) & 32.559 \\
Soybean oil & 1.787 \\
Dicalcium phosphate & 1.697 \\
Limestone & 0.853 \\
Salt & 0.474 \\
DL-methionine & 0.218 \\
L-lysine HCl & 0.181 \\
Choline chloride (60\%) & 0.125 \\
Premix & 0.250 \\
L-threonine & 0.033 \\
BHT & 0.010 \\
\hline & \\
\hline ME (kcal kg $\left.{ }^{-1}\right)$ & 3000 \\
Crude protein (\%) & 20.17 \\
Calcium (\%) & 0.840 \\
Available phosphorus (\%) & 0.422
\end{tabular}

continue 
continuation

$\begin{array}{lr}\text { Chlorine (\%) } & 0.330 \\ \text { Potassium (\%) } & 0.769 \\ \text { Sodium (\%) } & 0.207 \\ \text { Digestible lysine (\%) } & 1.096 \\ \text { Digestible methionine (\%) } & 0.491 \\ \text { Digestible methionine + cysteine (\%) } & 0.852 \\ \text { Digestible threonine (\%) } & 0.722\end{array}$

${ }^{1}$ Composition ton $^{-1}$ : folic acid: $150.00 \mathrm{mg}$; cobalt: $178.00 \mathrm{mg}$; copper: 2,675.00 mg; choline: $120.00 \mathrm{~g}$; iron: $11.00 \mathrm{~g}$; iodine: 535.00 mg; manganese: $31.00 \mathrm{~g}$; mineral matter: $350.00 \mathrm{~g}$; niacin: 7,200.00 mg; calcium pantothenate: 2,400.00 mg; selenium: $60.00 \mathrm{mg}$; vitamin A: 1,920,000.00 IU; vitamin B1: $300.00 \mathrm{mg}$; vitamin B12: 3,600.00 mg; vitamin B2: 1,200.00 mg; vitamin B6: $450.00 \mathrm{mg}$; vitamin D3: 360,000.00 IU; vitamin E: 3,600.00 IU; vitamin H: $18.00 \mathrm{mg}$; vitamin K: $480.00 \mathrm{mg}$; zinc: $22.00 \mathrm{~g}$.

T2: $70 \%$ control diet $+30 \%$ test ingredient (corn fertilized with crotalaria).

T3: $70 \%$ control diet $+30 \%$ test ingredient (corn fertilized with millet).

T4: $70 \%$ control diet $+30 \%$ test ingredient (corn fertilized with humus).

T5: 70\% control diet $+30 \%$ test ingredient (corn without fertilization).

The experimental period lasted 7 days. Broilers went through a period of adaptation to experimental diets for 4 days, and total excreta collection was carried out during the 3 subsequent days (RODRIGUES et al., 2005).

During the sampling period, the cage floor was covered with plastic to avoid contamination and any loss of excreta. Samples were collected twice a day (8 a.m. and 4 p.m.) to prevent fermentation. After each sampling, excreta were packed in plastic bags, properly identified and then finally were frozen for further analysis. At the end of the experimental period, the total amount of feed consumed and excreta produced were determined according to the methodology proposed by Sakomura and Rostagno (2016).
For analysis, $400 \mathrm{~g}$ of excreta from each treatment was defrosted at room temperature and homogenized. Subsequently, the samples were partially dried in a forced-ventilation oven at $55^{\circ} \mathrm{C}$ for $72 \mathrm{~h}$ to determine the oven-dry sample weight. Subsequently, the samples were processed in a knife-type mill with a 1-mm sieve and transported to the laboratory, along with feed samples.

Experimental diets and excreta samples were analysed at the laboratory of Tropical Animal Science at UFT, following the procedures described by Silva and Queiroz (2006). The dry matter (DM), crude protein (CP) and gross energy (GE) of the feed, experimental diets and excreta were determined.

After laboratory analysis, $\mathrm{AME}$ and $\mathrm{AME}_{\mathrm{n}}$ were determined using the equations proposed by Matterson et al. (1965).

$$
\text { Dietary AME }\left(\mathrm{kcal} \mathrm{kg}^{-1}\right)=\frac{\text { EMARR }+(\text { EMART }- \text { EMARR })}{\% \text { replacement }}
$$

Dietary $\operatorname{AME}_{\mathrm{n}}\left(\mathrm{kcal} \mathrm{kg}^{-1}\right)=\underline{\text { EMARRn }+\left(\text { EMARTn }^{-} \text {EMARRn }\right)}$

$\%$ replacement 
in which: $\mathrm{AME}=$ apparent metabolizable energy $\left(\mathrm{kcal} \mathrm{kg}^{-1}\right) ; \mathrm{AME}_{\mathrm{n}}=$ corrected apparent metabolizable energy $\left(\mathrm{kcal} \mathrm{kg}^{-1}\right)$; EMARR = apparent metabolizable energy of the reference diet; EMART $=$ apparent metabolizable energy of the test ration; and $\%$ substitution $=$ food $g$ ration ${ }^{-1}$.
The AMCDM, AMCCP and AMCGE of corn grown using different fertilizers were determined according to the equation described by Sakomura and Rostagno (2016):

\section{$\operatorname{AMC}(\%)=(\mathrm{g}$ of ingested nutrient $-\mathrm{g}$ of excreted nutrient $) \times 100$}

$\mathrm{g}$ of ingested nutrient

Data for energetic value and AMCDM, AMCCP and AMCGE of corn grown using different fertilizers were subjected to tests for normality (Cramer-Von Mises) and homoscedasticity (Levene). Variables for which these assumptions were met were subjected to analysis of variance. Means were compared by Student-Newman-Keuls (SNK) test at 5\% significance. Statistical analyses were performed using SAS 9.0 software (2002).

Trial II: Effect of different organic fertilizers in corn cultivation on performance of slow-growing broilers

A total of 250 slow-growing chicks (Red Naked Neck), 1 to 20 days old, and a mean initial weight of $38.3 \pm 3.15 \mathrm{~g}$ were used. Broilers were housed in experimental cages $(1.00 \times 1.00 \times 0.40 \mathrm{~m})$ located inside an experimental shed with a concrete floor, covered with Babassu straw and equipped with adjustable side curtains according to temperature and animal behaviour. The experimental cages were equipped with trough-type feeders and cuptype drinkers, which were cleaned and refilled twice a day to ensure free access to water and feed throughout the experimental period.

Broilers were distributed in a completely randomized experimental design (CRD) with five treatments ( $\mathrm{T} 1$ - control diet with commercial corn,
T2 - diet using corn without fertilization, T3 - diet using corn fertilized with humus, T4 - diet using corn fertilized with millet and T5 - diet using corn fertilized with crotalaria) and five replicates of 10 birds per experimental unit.

Experimental diets were formulated to meet the nutritional requirements of semi-heavy chickens in the growing phase, corrected for the average temperature in Araguaína, according to Rostagno et al. (2011) (Table 2).

Until 14 days old, broilers were heated artificially, using incandescent lamps $(60 \mathrm{~W})$ located inside the cages.

The performance variables evaluated were feed intake (FI), weight gain (WG), feed conversion (FC) and weight at 20 days. Feed intake was based on the amount of feed supplied and that remaining in the feeders; weight gain was measured by the difference between the final weight at the end of the trial and the initial weight. Feed conversion was the ratio of feed intake to weight gain.

Data were subjected to tests for normality (Cramer-Von Mises) and homoscedasticity (Levene). Variables for which these assumptions were met were subjected to analysis of variance. Means were compared by SNK test at 5\% significance. Statistical analyses were performed using SAS 9.0 software (2002). 
Table 2. Composition of experimental diets with corn grown using different organic fertilizers for slow-growing broilers from 1 to 20 days of age.

\begin{tabular}{|c|c|c|c|c|c|}
\hline \multirow[b]{2}{*}{ Ingredients } & \multicolumn{5}{|c|}{ Treatments } \\
\hline & $\begin{array}{c}\text { Control }^{2} \\
\text { diet }\end{array}$ & $\begin{array}{c}\text { Corn }^{3} \\
\text { test }\end{array}$ & $\begin{array}{l}\text { Corn }^{4} \\
\text { hum }\end{array}$ & $\begin{array}{l}\text { Corn } \\
\text { Millet }\end{array}$ & $\begin{array}{c}\text { Corn }^{6} \\
\text { crot }\end{array}$ \\
\hline Corn & 61.81 & 61.81 & 61.81 & 61.81 & 61.81 \\
\hline Soybean meal (45\%) & 32.56 & 32.56 & 32.56 & 32.56 & 32.56 \\
\hline Soybean oil & 1.787 & 1.787 & 1.787 & 1.787 & 1.787 \\
\hline Dicalcium phosphate & 1.697 & 1.697 & 1.697 & 1.697 & 1.697 \\
\hline Limestone & 0.853 & 0.853 & 0.853 & 0.853 & 0.853 \\
\hline Salt & 0.474 & 0.474 & 0.474 & 0.474 & 0.474 \\
\hline DL-methionine & 0.218 & 0.218 & 0.218 & 0.218 & 0.218 \\
\hline L-lysine $\mathrm{HCl}$ & 0.181 & 0.181 & 0.181 & 0.181 & 0.181 \\
\hline Choline chloride (60\%) & 0.125 & 0.125 & 0.125 & 0.125 & 0.125 \\
\hline Premix $^{1}$ & 0.250 & 0.250 & 0.250 & 0.250 & 0.250 \\
\hline L-threonine & 0.033 & 0.033 & 0.033 & 0.033 & 0.033 \\
\hline BHT & 0.010 & 0.010 & 0.010 & 0.010 & 0.010 \\
\hline Total & 100.00 & 100.00 & 100.00 & 100.00 & 100.00 \\
\hline \multicolumn{6}{|c|}{ Calculated nutritional composition } \\
\hline $\mathrm{ME}\left(\mathrm{kcal} \mathrm{kg}^{-1}\right)$ & 3000.0 & 3000.0 & 3000.0 & 3000.0 & 3000.0 \\
\hline Crude protein (\%) & 20.17 & 20.17 & 20.17 & 20.17 & 20.17 \\
\hline Calcium (\%) & 0.840 & 0.840 & 0.840 & 0.840 & 0.840 \\
\hline Available phosphorus (\%) & 0.422 & 0.422 & 0.422 & 0.422 & 0.422 \\
\hline Potassium (\%) & 0.769 & 0.769 & 0.769 & 0.769 & 0.769 \\
\hline Sodium $(\%)$ & 0.207 & 0.207 & 0.207 & 0.207 & 0.207 \\
\hline Digestible lysine (\%) & 1.096 & 1.096 & 1.096 & 1.096 & 1.096 \\
\hline Digestible methionine (\%) & 0.491 & 0.491 & 0.491 & 0.491 & 0.491 \\
\hline Digestible threonine $(\%)$ & 0.722 & 0.722 & 0.722 & 0.722 & 0.722 \\
\hline Digestible methionine + cysteine $(\%)$ & 0.852 & 0.852 & 0.852 & 0.852 & 0.852 \\
\hline Crude fibre (\%) & 2.828 & 2.828 & 2.828 & 2.828 & 2.828 \\
\hline Neutral detergent fibre (\%) & 11.864 & 11.864 & 11.864 & 11.864 & 11.864 \\
\hline Acid detergent fibre $(\%)$ & 4.717 & 4.717 & 4.717 & 4.717 & 4.717 \\
\hline
\end{tabular}

${ }^{1}$ Composition ton ${ }^{-1}$ : folic acid: $150.00 \mathrm{mg}$; cobalt: $178.00 \mathrm{mg}$; copper: 2,675.00 mg; choline: $120.00 \mathrm{~g}$; iron: $11.00 \mathrm{~g}$; iodine: 535.00 mg; manganese: $31.00 \mathrm{~g}$; mineral matter: $350.00 \mathrm{~g}$; niacin: 7,200.00 mg; calcium pantothenate: 2,400.00 mg; selenium: $60.00 \mathrm{mg}$; vitamin A: 1,920,000.00 IU; vitamin B1: $300.00 \mathrm{mg}$; vitamin B12: 3,600.00 mg; vitamin B2: 1,200.00 mg; vitamin B6: $450.00 \mathrm{mg}$; vitamin D3: 360,000.00 IU; vitamin E: 3,600.00 IU; vitamin H: $18.00 \mathrm{mg}$; vitamin K: $480.00 \mathrm{mg}$; zinc: $22.00 \mathrm{~g}$.

${ }^{2}$ Nutritional composition of the diet based on $\mathrm{AME}_{\mathrm{n}}$ of Rostagno et al. (2011). Only the control ration was formulated according to Rostagno; the others were added to the different corns following the control standard.

${ }^{3}$ Corn test: corn without fertilization.

${ }^{4}$ Corn hum: corn fertilized with humus.

${ }^{5}$ Corn millet: corn fertilized with millet.

${ }^{6}$ Corn crot: corn fertilized with crotalaria. 


\section{Results and Discussion}

Chemical composition, energy values and metabolizable coefficients of corn grown using different organic fertilizers

The average nutritional values of corn grains from crops fertilized with crotalaria, millet, humus, without fertilization and commercial corn (Table
3) were similar to those reported by Rostagno et al. (2011) for dry matter (87.33\% vs $87.48 \%$ ) but lower for gross energy (3830.6 vs $3940 \mathrm{kcal} \mathrm{kg}^{-1}$ ) and crude fibre (1.63\% vs $1.73 \%)$, whereas values were higher for crude protein $(8.58 \%$ vs $7.88 \%)$ and mineral matter $(1.42 \%$ vs $1.27 \%)$, in due order (Table 3).

Table 3. Nutritional composition of commercial corn and corn grown using different organic fertilizers ${ }^{1}$.

\begin{tabular}{lccccc}
\hline \multicolumn{1}{c}{ Item } & $\mathrm{DM}^{2}(\%)$ & $\mathrm{CP}^{3}(\%)$ & $\mathrm{MM}^{4}(\%)$ & $\mathrm{GE}^{5}\left(\mathrm{kcal} \mathrm{kg}^{-1}\right)$ & $\mathrm{CF}^{6}(\%)$ \\
\hline Commercial & 89.26 & 7.76 & 0.96 & 3912.53 & 1.68 \\
Fertilized with crotalaria & 85.31 & 8.31 & 1.69 & 3815.21 & 1.38 \\
Fertilized with millet & 88.31 & 7.32 & 1.63 & 3786.83 & 1.71 \\
Fertilized with humus & 88.00 & 10.02 & 1.54 & 3851.59 & 1.81 \\
Without fertilization & 85.76 & 9.50 & 1.26 & 3786.83 & 1.57 \\
Mean & 87.33 & 8.58 & 1.42 & 3830.60 & 1.63 \\
Maximum value & 89.26 & 10.02 & 1.69 & 3912.50 & 1.81 \\
Minimum value & 85.31 & 7.32 & 0.96 & 3786.83 & 1.38 \\
$\mathrm{CV}^{7}(\%)$ & 1.96 & 13.35 & 21.44 & 1.38 & 10.16 \\
\hline
\end{tabular}

${ }^{1}$ Values expressed on a dry matter basis.

${ }^{2} \mathrm{DM}=$ dry matter.

${ }^{3} \mathrm{CP}=$ crude protein.

${ }^{4} \mathrm{MM}=$ mineral matter.

${ }^{5} \mathrm{GE}=$ gross energy.

${ }^{6} \mathrm{CF}=$ crude fibre.

${ }^{7}$ Coefficient of variation (\%).

Dry matter values ranged from $85.31 \%$ to $89.26 \%$, similar to those reported by Vieira et al. (2007) for 45 corn hybrids ( $85.25 \%$ to $88.59 \%$ ) and by Nunes et al. (2008) (88.65\%). On the other hand, the values were lower than those reported by Henz et al. (2013) studying corn varieties under an organic system $(84.37 \%$ to $86.46 \%)$.

The gross energy values for the corns evaluated were lower than those reported by Vieira et al. (2014) studying corn hybrids, which varied from 3855 to $3967 \mathrm{kcal} \mathrm{kg}^{-1}$.

The average crude protein in the corns evaluated was $8.58 \%$, ranging from $7.32 \%$ to $10.02 \%$. These values were similar to those obtained by Agustini et al. (2015) for eight corn varieties that ranged from
$7.79 \%$ to $9.52 \%$, and to those reported by Vieira et al. (2014), Santos et al. (2005) and Piovesan et al. (2010), of $7.56 \%, 8.20 \%$ and $9.79 \%$, respectively.

The chemical composition of corn grains probably varied due to the different fertilization used in cultivation. The efficiency of organic fertilizers depends on their chemical composition, mineralization rate and nitrogen content which, in turn, are influenced by climatic conditions as they can be lost by volatilization (SILVA et al., 2015).

Crotalaria as a green manure, since it immobilizes in its tissues the nitrogen from biological fixation by the associated Rhizobium, has a lower $\mathrm{C} / \mathrm{N}$ ratio. It favours mineralization of its residues with less immobilization of the $\mathrm{N}$ by the soil microbiota, 
increasing the nutrient supply to the plants. On the other hand, millet as a green manure has greater immobilization of $\mathrm{N}$ by the microbial biomass of the soil during the decomposition of vegetal residues. It happens due to the high $\mathrm{C} / \mathrm{N}$ ratio of the material left on the soil surface, releasing nutrients in the medium and long term (CRUZ et al., 2018; SILVEIRA; FREITAS, 2007). The $\mathrm{C} / \mathrm{N}$ ratio of cover crops influences the mineralization rate of residues and, consequently, the release of $\mathrm{N}$ to crops grown in succession (DUCHENE et al., 2017; NICOLARDOT et al., 2001).

Humus was possibly partially mineralized, with a lower $\mathrm{C} / \mathrm{N}$ ratio, providing nutrients for the subsequent crop with lower $\mathrm{N}$ immobilization by the soil microbiota (KUMADA, 1987). This explains the highest value of protein found for corn fertilized with humus in the present study.

Relative to the soil without fertilization, since the experiment was in the third crop year, there was a biomass accumulation of previous crops in this plot. Then, in the medium and long term, the nutrients were made available for further cultivation cycles. This helps to explain the results obtained for the treatment of corn without fertilization.

There was a significant difference $(\mathrm{P}<0.05)$ between AMCDM and AMCGE (Table 4), which ranged from $80.38 \%$ to $89.75 \%$ and $78.95 \%$ to $88.5 \%$, respectively.

Table 4. Mean ( \pm standard error) of apparent metabolizable coefficients of dry matter (AMCDM), crude protein (AMCCP) and gross energy (AMCGE) of corn grown using different organic fertilizers.

\begin{tabular}{lccc}
\hline \multirow{2}{*}{\multicolumn{1}{c}{ Treatments }} & \multicolumn{3}{c}{ Variables } \\
\cline { 2 - 4 } & AMCDM $^{1}$ & AMCCP $^{1}$ & AMCGE $^{1}$ \\
\hline Corn fertilized with crotalaria & $89.75 \pm 2.69^{\mathrm{a}}$ & $66.88 \pm 0.87$ & $88.5 \pm 2.24^{\mathrm{a}}$ \\
Corn fertilized with millet & $84.38 \pm 5.17^{\mathrm{ab}}$ & $58.73 \pm 9.20$ & $81.4 \pm 4.88^{\mathrm{ab}}$ \\
Corn fertilized with humus & $80.38 \pm 3.58^{\mathrm{b}}$ & $53.45 \pm 10.73$ & $78.95 \pm 2.83^{\mathrm{b}}$ \\
Corn without fertilization & $89.48 \pm 4.43^{\mathrm{a}}$ & $68.95 \pm 8.95$ & $87.85 \pm 4.42^{\mathrm{a}}$ \\
$\mathrm{CV}^{2}(\%)$ & 4.75 & 13.51 & 4.48 \\
${\mathrm{P}>\mathrm{F}^{3}}$ & 0.0222 & 0.0749 & 0.0082 \\
\hline
\end{tabular}

${ }^{1}$ Means followed by same letters in the column did not differ by SNK test $(\mathrm{P}>0.05)$.

${ }^{2}$ Coefficient of variation (\%).

${ }^{3}$ ANOVA F-test.

Corn fertilized with crotalaria and without fertilization had greater AMCDM and AMCGE than corn fertilized with humus, but neither differed from corn fertilized with millet.

The AMCGE values for corn grown using different organic fertilizers were higher than $70 \%$, which demonstrated a suitable use of metabolizable energy. According to Conte et al. (2002), corn has a high AME coefficient because it is rich in starch and poor in structural carbohydrates.
The AME and $\mathrm{AME}_{\mathrm{n}}$ differed $(\mathrm{P}<0.05)$ among treatments, ranging from 2909 to $3246 \mathrm{kcal} \mathrm{kg}^{-1}$ and 2877 to $3239 \mathrm{kcal} \mathrm{kg}^{-1}$ (Table 5), respectively. The values were lower than those found by Henz et al. (2013) in five corn cultivars under organic fertilization for 21-day-old broilers, of 3113 to 3325 kcal $\mathrm{kg}^{-1}$ for AME and 3059 to $3287 \mathrm{kcal} \mathrm{kg}^{-1}$ for $\mathrm{AME}_{\mathrm{n}}$.

Corn fertilized with crotalaria and without fertilization had the highest values for AME and 
$\mathrm{AME}_{\mathrm{n}}$, whereas corn fertilized with millet and humus had the lowest values. This probably happened because organic fertilizers have different mineralization rates, varying nutrient availability to crops and, consequently, affecting their energy values.

Crotalaria, when incorporated into the soil, probably increased nutrient supply to corn due to the lower $\mathrm{C} / \mathrm{N}$ ratio, favouring the mineralization of its residues, with lower $\mathrm{N}$ immobilization by the soil microbiota. Corn cultivated without fertilization, considering the experiment in the third crop year, favoured the biomass accumulation of previous corn crops, and in the medium and long term, the nutrients were made available for further cultivation cycles. This fact explains the high AME and AME results obtained for treatment with corn fertilized with crotalaria and corn without fertilization.

Table 5. Mean ( \pm standard error) of apparent metabolizable energy (AME) and apparent metabolizable energy corrected for nitrogen balance $\left(\mathrm{AME}_{\mathrm{n}}\right)$ of corn grown using different organic fertilizers ${ }^{1}$.

\begin{tabular}{lcc}
\hline \multirow{2}{*}{ Treatments } & \multicolumn{2}{c}{ Variables } \\
\cline { 2 - 3 } & $\mathrm{AME}\left(\mathrm{kcal} \mathrm{kg}^{-1}\right)^{2}$ & $\mathrm{AME}_{\mathrm{n}}\left(\mathrm{kcal} \mathrm{kg}^{-1}\right)^{2}$ \\
\hline Corn fertilized with crotalaria & $3246 \pm 43^{\mathrm{a}}$ & $3239 \pm 44^{\mathrm{a}}$ \\
Corn fertilized with millet & $2954 \pm 94^{\mathrm{b}}$ & $2965 \pm 88^{\mathrm{b}}$ \\
Corn fertilized with humus & $2909 \pm 55^{\mathrm{b}}$ & $2877 \pm 45^{\mathrm{b}}$ \\
Corn without fertilization & $3265 \pm 85^{\mathrm{a}}$ & $3201 \pm 78^{\mathrm{a}}$ \\
$\mathrm{CV}^{3}(\%)$ & 4.67 & 4.34 \\
$\mathrm{P}>\mathrm{F}^{4}$ & 0.0063 & 0.0055 \\
\hline
\end{tabular}

${ }^{1}$ Values expressed on an organic matter basis.

${ }^{2}$ Means followed by same letters in the column did not differ by SNK test $(\mathrm{P}>0.05)$.

${ }^{3}$ Coefficient of variation (\%).

${ }^{4}$ ANOVA F-test.

Performance of slow-growing broilers fed corn grown using different organic fertilizers

Feeding corn grown with different organic fertilizers to slow-growing broilers affected $(\mathrm{P}<$ 0.05 ) the feed intake, weight gain, feed conversion and the weight at 20 days in the 1- to 20-days-old phase (Table 6).

Table 6. Average feed intake (FI), weight gain (WG), feed conversion (FC) and weight at 20 days (W20d) in slowgrowing broilers fed corn grown using different organic fertilizers.

\begin{tabular}{lcccc}
\hline \multirow{2}{*}{ Treatments } & \multicolumn{3}{c}{ Variables } \\
\cline { 2 - 5 } \multicolumn{1}{c}{ FI $(\mathrm{g})$} & $565.42^{\mathrm{a}}$ & $327.28^{\mathrm{a}}$ & $1.73^{\mathrm{a}}$ & $366.44^{\mathrm{a}}$ \\
\hline Control diet & $347.17^{\mathrm{b}}$ & $180.29^{\mathrm{b}}$ & $1.94^{\mathrm{b}}$ & $233.61^{\mathrm{b}}$ \\
Corn without fertilization & $537.8^{\mathrm{a}}$ & $320.16^{\mathrm{a}}$ & $1.68^{\mathrm{a}}$ & $358.46^{\mathrm{a}}$ \\
Corn fertilized with humus & $564.9^{\mathrm{a}}$ & $342.32^{\mathrm{a}}$ & $1.65^{\mathrm{a}}$ & $380.7^{\mathrm{a}}$ \\
Corn fertilized with millet & $538.9^{\mathrm{a}}$ & $332.28^{\mathrm{a}}$ & $1.62^{\mathrm{a}}$ & $364.3^{\mathrm{a}}$ \\
Corn fertilized with crotalaria & 5.21 & 5.04 & 6.01 & 5.19 \\
$\mathrm{CV}^{1}(\%)$ & 0.0001 & 0.0001 & 0.0017 & 0.0001 \\
$\mathrm{P}>\mathrm{F}^{2}$ & & & & . \\
\hline
\end{tabular}

${ }^{1}$ Coefficient of variation (\%).

${ }^{2}$ ANOVA F-test. 
Corn fertilized with humus, millet, crotalaria and commercial corn did not differ and had the best results for the variables evaluated, the worst results being verified for the treatment using corn cultivated without fertilization. This probably happened due to fungus development and the production of mycotoxins during crop development; it was evidenced when the corn was ground and stored in cold rooms, negatively influencing the treatment using corn without fertilization.

The presence of aflatoxin (127.20 ppb) above the maximum admissible concentration limits in Brazil (20 ppb) according to the current legislation (BRASIL, 2011) was verified in the CBO laboratory (Campinas, SP). Therefore, broilers fed corn without fertilization had decreased performance due to the reduction in feed intake, possibly caused by the production of aflatoxin.

Unfavourable storage conditions (high temperatures and inadequate humidity) and fungus action may change the free fatty acid content and may also lead to grain heating and mycotoxin production, compromising the nutritional quality of grains and causing metabolic disturbances in the animals (HENZ et al., 2013; PINTO, 2007).

Performance data confirmed the result of the metabolic assay, in which the metabolizable coefficients of dry matter and crude energy were ranked in descending order for the treatments as follows: crotalaria, without fertilization, millet and humus. Treatment using corn cultivated without fertilization could have a better performance result, but it was compromised by the fungus action as evidenced by the aflatoxin analysis.

Corn grown using different fertilizers has the potential to be used for feeding slow-growing broilers in the initial phase (from 1 to 20 days old), not differing from the commercial diet but with the advantage of not using chemical fertilizers. However, more research on the use of grains grown with different fertilizers for feeding backyard poultry in all breeding phases is necessary.

\section{Conclusion}

The use of crotalaria and millet as green manure, and humus derived from dairy manure are alternatives that may be used on corn crop as they resulted in grains with adequate nutritional composition, energy values and metabolizable coefficients for slow-growing broilers from 1 to 20 days of age.

\section{Acknowledgments}

The authors thank the National Council for Scientific and Technological Development $(\mathrm{CNPq})$ for financial support, Coordination for the Improvement of Higher Education Personnel (CAPES) for granting of scholarships, and the School of Veterinary Medicine and Postgraduate Program in Tropical Animal Science, UFT, for the opportunity of Animal Science graduation and Masters in Tropical Animal Science.

\section{References}

AGUSTINI, M. A. B.; NUNES, R. V.; SILVA, Y. L. da.; VIEITES, F. M.; EYNG, C.; CALDERANO, A. A.; GOMES, P. C. Coeficiente de digestibilidade e valores de aminoácidos digestíveis verdadeiros de diferentes cultivares de milho para aves. Semina: Ciências Agrárias, Londrina, v. 36, n. 2, p. 1091-1098, 2015.

ALBINO, L. F. T.; ROSTAGNO, H. S.; TAFURI, M. L.; SILVA, M. de A. Determinação dos valores de energia metabolizável aparente e verdadeira de alguns alimentos para aves, usando diferentes métodos. Revista da Sociedade Brasileira de Zootecnia, Viçosa, MG, v. 21, n. 6, p. 1047-1058, 1992.

BARROS, J. D. S.; SILVA, M. F. P. Práticas agrícolas sustentáveis como alternativas ao modelo hegemônico de produção agrícola. Sociedade e Desenvolvimento Rural, Brasília, v. 4, n. 2, 2010. Disponível em: <http:www. inagrodf.com.br/revista $>$. Acesso em: 10 maio 2018.

BRASIL. Agência Nacional de Vigilância Sanitária. Resolução da ANVISA RDC No. 7 de 18 de fevereiro de 2011. Diretoria Colegiada da Agência Nacional de Vigilância Sanitária, Brasília, 9 mar. 2011. Seção 1, p. 66-67. Disponível em: <http://portal.anvisa.gov.br/ wps/wcm/connect/ bc17db804f 45 fe2cbd41fdd785749f 
bd/Resolu\%C3\%A7\%C3\%A3o+0-2011-GGALI. pdf?MOD=AJPERES $>$. Acesso em: 6 abr. 2018.

BRASIL. Ministério da Agricultura, Pecuária e Abastecimento. MAPA - Milho. Brasília: EMBRAPA, 2017. Disponível em: <http://www.agricultura.gov.br/ vegetal/culturas/milho>. Acesso em: 20 maio 2017.

CONTE, A. J.; TEIXEIRA, A. S.; BERTECHINI, A. G. Efeito da fitase e xilanase sobre a energia metabolizável do farelo de arroz integral em frangos de corte. Ciencia Agrotecnologia, Lavras, v. 26, n. 6, p. 1289-1296, 2002.

CRUZ, J. C.; ALVARENGA, R. C.; VIANA, J. H. M.; PEREIRA, I. A. P. F.; ALBURQUERQUE, M. R. F de.; SANTANA, D. P. Sistema de plantio direto de milho EMBRAPA. Brasília: Ageitec, 2018. Disponível em: $<$ https://www.agencia.cnptia.embrapa.br/gestor/milho/ arvore/CONTAG01_72_59200523355.html $>$. Acesso em: 2 fev. 2018.

DUCHENE, O.; VIAN, J. F.; CELETTE, F. Intercropping with legume for agroecological cropping systems: complementarity and facilitation processes and the importance of soil microorganisms. A review. Agriculture, Ecosystems \& Environment, Amsterdã, v. 240, n. 1, p. 148-161, 2017.

COMUNIDADE ECONÔMICA EUROPÉIA - CEE. Lei CEE no 2092/91. Produção biológica de produtos agrícolas. Estados Unidos: CEE, 24 jun. 1991.

FRANCESCHI, L. de; BENIN, G.; GUARIENTI, E.; MARCHIORO, V. S.; MARTIN, T. N. Fatores précolheita que afetam a qualidade tecnológica de trigo. Ciência Rural, Santa Maria, v. 39, n. 5, p. 1624-1631, 2009.

HENZ, J. R.; NUNES, R. V.; POZZA, P. C.; FURLAN, A. C.; SCHERER, C.; EYNG, C.; SILVA, W. T. M. da. Valores energéticos de diferentes cultivares de milho para aves. Semina: Ciências Agrárias, Londrina, v. 34, n. 5, p. 2403-2414, 2013.

KUMADA, K. Chemistry of soil organic matter. Toyko: Japan Scientific Societies Press, 1987. 241 p.

MADEIRA, L. A.; SARTORI, J. R.; ARAUJO, P. C.; PIZZOLANTE, C. C.; SALDANHA, É. S. P. B.; PEZZATO, A. C. Avaliação do desempenho e do rendimento de carcaça de quatro linhagens de frangos de corte em dois sistemas de criação. Revista Brasileira de Zootecnia, Viçosa, MG, v. 39, n. 10, p. 2214-2221, 2010.

MATTERSON, L. D.; POTTER, L. M.; STUTZ, M. W.; SINGSEN, E. P. The metabolizable energy of feed ingredients for chickens. Research Report, Connecticut, v. 1 , n. 7, p. 3-11, 1965.
MORAIS, J.; FERREIRA, P. B.; JACOME, I. M. T. D.; MELLO, R.; BREDA, F. C.; RORATO, P. R. N. Curva de crescimento de diferentes linhagens de frango de corte caipira. Ciência Rural, Santa Maria, v. 45, n. 10, p. 18721878, out. 2015.

NICOLARDOT, B.; RECOUS, S.; MARY, B. Simulation of $\mathrm{C}$ and $\mathrm{N}$ mineralisation during crop residue decomposition: a simple dynamic model based on the $\mathrm{C} / \mathrm{N}$ ratio of the residues. Plant and Soil, Dordrecht, v. 228, n. 1, p. 83-103, 2001.

NUNES, R. V.; ROSTAGNO, H. S.; GOMES, P. C.; NUNES, C. G. V.; POZZA, P. C.; ARAUJO, M. S. de. Coeficientes de metabolizabilidade da energia bruta de diferentes ingredientes para frangos de corte. Revista Brasileira de Zootecnia, Viçosa, MG, v. 37, n. 1, p. 8994, 2008.

PINTO, N. F. J. de A. Reação de cultivares com relação à produção de grãos ardidos em milho. Sete Lagoas: EMBRAPA Milho e Sorgo (CNPMS), dez. 2007. 4 p. (Comunicado técnico, 144).

PIOVESAN, V.; OLIVEIRA, V. de; ARAÚJO, J. dos S. Predição do conteúdo de aminoácidos essenciais do grão de milho. Ciência e Agrotecnologia, Lavras, v. 34, n. 3, p. 758-764, 2010.

RODRIGUES, P. B.; MARTINEZ, R. de S.; FREITAS, R. T. F. de; BERTECHINI, A. G.; FIALHO, E. T. Influência do tempo de coleta e metodologias sobre a digestibilidade e o valor energético de rações para aves. Revista Brasileira de Zootecnia, Viçosa, MG, v. 34. n. 3, p. 882-889, 2005.

ROSTAGNO, H. S.; ALBINO, L. F. T.; DONZELE, J. L.; GOMES, P. C.; OLIVEIRA, R. F. de; LOPES, D. C.; FERREIRA, A. S.; BARRETO, S. L. de T.; EUCLIDES, R. F. Tabelas brasileiras para aves e suínos composição de alimentos e exigências nutricionais. 3. ed. Viçosa, MG: UFV, Imprensa Universitária, 2011. 252 p.

SAKOMURA, N. K.; ROSTAGNO, H. S. Métodos de pesquisa em pesquisa em nutrição de monogástricos. Jaboticabal: UNESP, 2016. 283 p.

SANTOS, Z. A. S.; FREITAS, R. T. F.; FIALHO, E. T.; RODRIGUES, P. B.; LIMA, J. A. F.; CARELLO, D. C.; BRANCO, P.A.C.; CANTARELLI, V. S. Valor nutricional de alimentos para suínos determinado na Universidade Federal de Lavras. Ciência e Agrotecnologia, Lavras, v. 29, n. 1, p. 232-237, 2005.

SIBBALD, I. R. A bioassay for the true metabolizable energy in feedstuffs. Poultry Science, Ottawa, v. 55, n. 1, p. 303-308, 1976. 
SIBBALD, I. R.; SLINGER, S. J. A. Biological assay for metabolizable energy in poultry feed ingredients together with findings which demonstrate some of the problems associated with the evaluation of fats. Poultry Science, Ottawa, v. 42, n. 2, p. 313-325,1963.

SILVA, D. J.; QUEIROZ, A. C. Análise de alimentos: métodos químicos e biológicos. 3. ed. Viçosa, MG: UFV, 2006. 235 p.

SILVA, G. F. da; MAPELI, N. C.; CREMON, C.; CAMILO, I. C. V. S.; SILVA, A. N. da. Influência de diferentes fontes de adubos no desenvolvimento e no teor de betacaroteno em espinafre. Cadernos de Agroecologia, Brasília, v. 10, n. 3, p. 1, 2015.

SILVEIRA, A. P. D. da; FREITAS, S. dos S. Microbiota do solo e qualidade ambiental. Campinas: Instituto Agronômico, 2007. 312 p.
STATISTICAL ANALYSES SYSTEM - SAS. SAS/ INSIGHT User's Guide. Versão 9.0- versão para Windows. Cary: SAS Institute, 2002. CD-ROM.

VIEIRA, R. A.; ALBINO, L. F. T.; HANNAS, M. I.; VIANA, G. da S.; MUNIZ, J. C. L.; SILVA, D. L. da; JUNIOR, V. R.; REIS, J. V. C. Composição química e valores de energia metabolizável aparente corrigida de alguns alimentos energéticos determinados com frango de corte. Revista Brasileira de Agropecuária Sustentavel, Viçosa, MG, v. 4, n. 2, p. 75-83, 2014.

VIEIRA, R. O.; RODRIGUES, P. B.; FREITAS, R. T. F. Composição química e energia metabolizável de híbridos de milho para frango de corte. Revista Brasileira de Zootecnia, Viçosa, MG, v. 36, n. 4, p. 832-838, 2007. 
